\title{
The holotype of Leaia silurica Matthew, 1910, Pennsylvanian, Lancaster Formation, New Brunswick
}

\author{
Randall F. Miller \\ Steinhammer Palaeontology Laboratory, New Brunswick Museum, \\ Saint John, New Brunswick E2K 1E5, Canada
}

Date Received March 23, 1995

Date Accepted March 27, 1995

\begin{abstract}
The conchostracan Leaia silurica Matthew, 1910 was reviewed by Copeland in 1957 and a hypotype described and deposited in the collections of the Geological Survey of Canada. Matthew's holotype has been recovered during organization of the G.F. Matthew collection at the New Brunswick Museum.

Le Conchostracé Leaia silurica de Matthew, 1910, a été réexaminé par Copeland en 1957 et un hypotype a été décrit et déposé dans les collections de la Commission géologique du Canada. L'holotype de Matthew a été récupéré pendant l'organisation de la collection de G. F. Matthew au Musée du Nouveau-Brunswick.
\end{abstract}

[Traduit par la rédaction]

\section{INTRODUCTION}

In 1909, G.F. Matthew described a new species of conchostracan, Leaia silurica (Matthew, 1910, p. 115, pl. IV, fig. 3), from the "Fern Ledges" locality (Pennsylvanian, Westphalian B, Lancaster Formation, Cumberland Group; Williams et al., 1985), Saint John, New Brunswick. The description of $L$. silurica was based on a specimen collected by William McIntosh from the "Lower Cordaite Shales (black shale beneath Hartt's Bed No. 2?)". As with most of Matthew's type specimens from the "Fern Ledges", the fossils were warehoused and inaccessible for almost 50 years. Later authors commonly assumed Matthew's specimens were lost and presumably for this reason Copeland (1957) designated a hypotype of $L$. silurica (G.S.C. 12818, Bolton, 1966).

\section{DesCription}

Among recent discoveries in the New Brunswick Museum collections are two specimens (NBMG 4573a, b; part and counterpart) labelled Leaia cf. leidyi. There is little doubt the specimens represent Matthew's holotype of Leaia silurica. NBMG 4573a most closely resembles Matthew's illustration of $L$. silurica (Matthew, 1910, p. 133, pl. IV, fig. 3). The specimens may have suffered flaking around the margin and do not exactly match Matthew's illustration, although his drawings were sometimes based on composites and included inferred detail. The original labels include the identification "Leaia cf. Leidyi Jones" and state the specimen "has fewer ribs than that sp.". The description continues "flattened in soft dark shale", "L. Cord. Fern Ledges", "coll. W. McIntosh '08". This is consistent with Matthew's published description that states "This species is allied to $L$. Leidyi of the Coal-measures of Pennsylvania, but has fewer concentric ridges..." and with the locality and collector information "Found by Mr. Wm. McIntosh" (Matthew, 1910, p. 115). Although no information concerning etymology of the species name was given, by 1910 Matthew believed the Lancaster Formation was Silurian (Stopes, 1914). NBMG 4573a, b show limited characters as described by Copeland (1957) although a key feature of two symmetrical radial carinae is present.

\section{Discussion}

Copeland's (1957) survey of Carboniferous arthropods of the Maritime Provinces included L. silurica with a description based on Matthew's illustration and new specimens from the Canso Group at Brown's Brook, Nova Scotia (Hypotype G.S.C. 12818 from GSC Locality 12253) and the Pictou Group at Barrington Cove (GSC Locality 1521), Nova Scotia; the Cumberland Group, Lancaster Formation at Fern Ledges, Saint John, New Brunswick (GSC Locality 2254) and the same formation near Milkish Head east of Saint John at GSC Locality 1684, collected by A.O. Hayes in 1913. However, a problem exists since Milkish Head is located north of Saint John. The file description for GSC Locality 1684 (Milkish Head, near Saint John, on coast about 1 mile north-northwest of Summerside [probably Summerville] Ferry Landing, south side of Peninsula) places it in the Mississippian, Kennebacasis Formation (McLeod et al., 1994) near a plant fossil locality at Polly Sams Point $\left(45^{\circ} 20^{\prime} 30^{\prime \prime N}\right.$; $\left.66^{\circ} 07^{\prime} 30^{\prime \prime} \mathrm{W}\right)$. GSC Locality 1684 also contains two additional branchiopods, Asmussia alta (Raymond) and $A$. tenella (Bronn) (Copeland, 1957). Fossil bearing Pennsylvanian rocks of the Tynemouth Creek Formation do outcrop east of Saint John at McCoy Head, although no evidence has been uncovered to suggest this may have been Hayes' locality. 
Bolton, T.E. 1966. Catalogue of Type Invertebrate Fossils of the Geological Survey of Canada, Volume 3. Department of Mines and Technical Surveys Canada, Ottawa, 203 p.

Copeland, M.J. 1957. The arthropod fauna of the Upper Carboniferous rocks of the Maritime Provinces. Geological Survey of Canada, Memoir 286, 110 p.

Matthew, G.F. 1910 (1909). Remarkable forms of the Little River Group. Transactions of the Royal Society of Canada, 3, pp. 115-133

McLeod, M.J., Johnson, S.C., and Ruitenberg, A.A. 1994. Geo- logical Map of Southwestern New Brunswick. Department of Natural Resources and Energy, Mineral Resources Map NR-5.

Stopes, M.C. 1914. The "Fern Ledges" Carboniferous flora of St. John, New Brunswick. Canada Department of Mines, Geological Survey, Memoir 41, 142 p.

Williams, G.L., Fyffe, L.R., Wardle, R.J., Colman-SAdD, S.P., and Boenner, R.C. 1985. Lexicon of Canadian Stratigraphy, Volume VI, Atlantic Region. Canadian Society of Petroleum Geologists, Calgary, 572 p.

Editorial responsibility: R.K. Pickerill 